Вестник ВГУ. Серия: Право

УДК 34.01

DOI https://doi.org/10.17308/vsu.proc.law.2020.3/2970

\title{
КОНЦЕПЦИЯ НРАВСТВЕННОЙ ВЛАСТИ ЙОЗЕФА РАТЦИНГЕРА
}

\author{
Е. А. Костенникова
}

Всероссийский государственный университет юстииии

(РПА Минюста России)

Поступила в редакцию 17 марта 2020 г.

\begin{abstract}
Аннотация: проводится анализ научных изысканий совреленного католического мыслителя Й. Ратиингера. Автор исследует взгляды Ратиингера на сущность и характер политической власти, роль государства в обществе, а также на отношения личности и государства. В процессе расслотрения кониепиии Й. Ратиингера автор приходит к выводу, что рассуждения мыслителя основываются на положениях христианской доктрины. В работе показано, что, колментируя тексты Священного Писания, ученьй представляет фборлулу «идеальной» власти, раскрывает ее структуру. Результатом проведенного исследования является определение и интерпретация концептуальных молентов учения Й. Ратиингера о власти. Ключевые слова: власть, государственная власть, нравственность, иерковь, христианство, христианская доктрина.
\end{abstract}

Abstract: this article gives an analysis of select studies by contemporary Catholic thinker Joseph Ratzinger. The author makes a study of Ratzinger's views on the essence and character of political power, its role in society, and on the relations between the State and the person. In course of this work the author concludes that Ratzinger's reasoning is based on Christian doctrine. It is shown that, expounding on Holy Scripture, Ratzinger presents a formula of "ideal" authority and breaks down its structure. In conclusion, key points of J. Ratzinger's concept of political authority are revealed and interpreted.

Key words: authority, political power, morality, church, Christianity, Christian doctrine.

Генезис, развитие и жизнедеятельность любой государственно-правовой системы имеют в своей основе ряд фракторов, которые определяют нравственно-культурный характер конкретного общества и государства.

40 Так, западная цивилизация формировалась на основе христианства, которое, будучи религией, стало для европейского и позже американского общества частью культуры и ментальности. Несмотря на то что эпоха Просвещения, а затем и модернистские течения подорвали христианскую основу, философрккая и социально-политическая мысль во многом сохранила связь с христианской доктриной ${ }^{1}$. Христианство не уходит с социально-политической сцены и сохраняет мощное влияние, благодаря его постоянному возрождению в духовной сфере людей, в том числе

\footnotetext{
${ }^{1}$ В частности, экзистенциалистские концепции Г. Марселя, Ж. Маритена и др. Обращение к христианству также присутствует в идеологии постмодерна.

(C) Костенникова Е. А., 2020
} 


\section{Государственная власть. Законодательный процесс...}

общественных деятелей и политических акторов. Все это оказывается возможным благодаря личностям, обладающим невероятной харизмой, таким как папа Иоанн Павел II, и благодаря выдающимся богословам, труды которых оказывают огромное влияние на духовную и социальную жизнь не только на Западе, но и в России. К последним мы можем отнести Й. Ратцингера - папу римского Бенедикта XVI, который в настоящее время носит титул «Рара Emiritus» - «папа римский на покое».

Будучи приверженцем патристики, строгим әкзегетом и традиционалистом, Й. Ратцингер, на первый взгляд, не создал самостоятельную концепцию власти и права. Тем не менее можно утверждать, что политико-правовая мысль ощутимо присутствует в подавляющем большинстве его работ и заслуживает того, чтобы считаться философской и политико-правовой доктриной. Й. Ратцингер - последовательный консерватор, в основе его воззрений на проблемы государства, власти и политического управления лежит традиционное учение католической церкви, отправной точкой которого являются два новозаветных текста. Первый - известный всем, но не теряющий актуальности, отрывок из послания святого апостола Павла к римлянам, где Павел излагает идею о необходимости установления власти, которая обеспечивала бы нравственный порядок, соответствующий Божественному замыслу: «Всякая душа да будет покорна высшим властям: ибо нет власти не от Бога; существующие же власти от Бога установлены. Посему противящийся власти противится Божию установлению. А противящиеся сами навлекут на себя осуждение» (Рим. 13:1-2).

Второй отрывок - из послания святого апостола Петра. Здесь апостол точно так же требует покорности законной власти «для Господа»: «Итак будьте покорны всякому человеческому начальству, для Господа: царю ли, как верховной власти, правителям ли, как от него посылаемым для наказания преступников и для поощрения делающих добро» (1 Петр. 2:13-14).

Следуя завету апостолов, социальная доктрина католической церкви признает, что государство является необходимой институцией, без которой невозможны ни порядок, ни плодотворная жизнь членов общества. В пастырской конституции "Gaudium et Spes» подчеркивается, что создание политических сообществ, в том числе государства, заложено человеческой природой, и наличие власти так же отвечает человеческим потребностям, как единственное средство управления и упорядочения, склонного к разобщению социума ${ }^{2}$. Поэтому католическая церковь предписывает «отдавать власти долженствующие ей почести, окружать уважением и, согласно заслугам, благодарностью и доброжелательством лиц, на которых она возложена» ${ }^{3}$.

Вместе с тем католическая доктрина далека от того, чтобы призывать к безусловному поклонению власти как таковой. Подчинение власти ос-

${ }^{2}$ Пастырская конституция Второго Ватиканского собора «Gaudium et Spes», п. 74-75 // Второй Ватиканский собор : Конституции. Декреты. Декларации. Брюссель, 1992. С. 404-405.

${ }^{3}$ Катехизис католической церкви. Ст.1900. М., 2001. С. 448. 


\section{Вестник ВГУ. Серия: Право}

новывается на осознанной необходимости и полезности государственных установлений. Подчинение власти - свободный выбор человека. При этом чтобы вызывать уважение и поддержку, власть сама должна отвечать определенным требованиям. Это подтверждает и апостол Петр: «Такова есть воля Божия, чтобы мы, делая добро, заграждали уста невежеству безумных людей, - как свободные, а не как употребляющие свободу для прикрытия зла» (1 Петр. 2:15-16).

То есть, будучи сама частью Божественного замысла, государственная власть должна быть направлена на установление общественного порядка, который в полной мере этот замысел реализует. Она должна служить общему благу, а не попустительствовать «невежеству и безумию».

Й. Ратцингер, анализируя новозаветные тексты, отмечает, что сходный смысл и основание имеет ответ Иисуса фрарисеям, задавшим вопрос о податях: принадлежащее кесарю необходимо отдавать кесарю (Мк. 12:13$17)^{4}$. Из данного отрывка следует, что римский император, выступая гарантом права, может требовать повиновения. Однако это повиновение имеет свои пределы: есть вещи, принадлежащие кесарю, а есть принадлежащие Богу, поэтому, если власть государя претендует на равенство Божьей, то повиновение становится отрицанием самого Бога.

Еще один пример - диалог Христа с Понтием Пилатом. Иисус знает, что Пилат - неправедный судья, тем не менее признает за ним власть и само право вершить правосудие: «Ты не имел бы надо Мною никакой власти, если бы не было дано тебе свыше; посему более греха на том, кто предал Меня тебе» (Ин. 19:11).

Й. Ратцингер вовсе не требует, чтобы государство носило религиозный характер, а правители были верующими. Он утверждает, что личная религиозность и добрые намерения вообще не имеют значения для реализации предназначения публичной власти. В любом случае, гарантируя мир и право, государство оказывается звеном в цепи творения. При этом политическая власть функционирует не механически, но, прежде всего, как нравственная сила, опирающаяся на свободу и осознание принимаемых обязанностей. Тогда граждане обязаны выказывать ей «повиновение по совести» ${ }^{5}$. По словам Й. Ратцингера, «государство заслуживает уважения именно в своей профанности, оно необходимо ввиду того, что человек по своей сути есть animal sociale et politicum (существо общественное и политическое. $-E . K$.), и обоснование государства - в такой его сущности, а значит, в самом порядке творения» ${ }^{6}$.

Таким образом, Й. Ратцингер предлагает пересмотреть и переоценить роль и полномочия политической власти в современных государ-

${ }^{4}$ Ratzinger J. Europe Today and Tomorrow: Addressing the Fundamental Issue. San Francisco, 2007. P. 51-52.

${ }^{5}$ Пастырская конституция Второго Ватиканского собора «Gaudium et Spes», п.74 // Второй Ватиканский собор : Конституции. Декреты. Декларации. Брюссель, 1992. С. 404.

${ }^{6}$ Ratzinger $J$. Europe Today and Tomorrow: Addressing the Fundamental Issue. P. 52 . 


\section{Государственная власть. Законодательный процесс...}

ствах с точки зрения соответствия Божественному замыслу и способности отвечать вызовам настоящего времени.

Развивая эту мысль, ученый обращается к истории и приводит интересное наблюдение. Когда христиане Древнего Рима искали выражение, с помощью которого можно было бы описать значение Христа, они первоначально использовали латинский термин «Conservator mundi» - хранитель мира, употребляемый в то время по отношению к самой Римской империи - главному источнику мирного порядка и правовых гарантий ${ }^{7}$.

Однако путь Христа к воскресению ясно демонстрировал необходимость изменения всех аспектов человеческой жизни - чувств, желаний, ориентиров, и христиане избрали иной термин - «Salvator mundi» - спаситель мира, который, хотя и не имел политического подтекста, указывал на «измерение человеческого бытия, явно выходящее за рамки политических функций поддержания мира и порядка» ${ }^{8}$.

Но вернемся к первоначальному термину «хранитель». Здесь возникает логичный, на наш взгляд, вопрос: почему христиане Древнего Рима, даже подвергаясь жестоким гонениям со стороны государства, не отказывали ему в заслугах и положительных свойствах, а некоторые из них выбирали в качестве образца и примера?

За ответом обратимся к трудам духовного учителя Й. Ратцингера Августина Аврелия. Его политико-правовое учение является той почвой, на которой возрастали все последующие богословские концепции о государстве и праве, и мы также не можем обойти его вниманием.

Источником и субстанщией всего сущего, согласно Августину, является Бог. Так и «человеческие царства устраиваются божественным провидением», и власть "раздавать царствования и правления» присуща единственно Богу9. В связи с этим епископ Иппонийский полагает, что государственной власти должно быть присуще стремление к справедливости и добродетели. Вспомним его знаменитое сравнение лишенного справедливости государства с «шайкой разбойников», которая, по сути, представляет собой некое «государство в миниатюре»: оба они - сообщества людей, управляются властью начальника, связаны соглашением и делят добычу по добровольно установленному закону. «Прекрасно и верно, - пишет Августин Аврелий, - ответил Александру Великому один пойманный пират, когда царь спросил его, какое право имеет он грабить на море. Тот дерзко отвечал: «Такое же, какое и ты: но поскольку я делаю это на небольшом судне, меня называют разбойником; ты же располагаешь огромным фолотом, и потому тебя величают императором» ${ }^{10}$.

Отношение святого Августина к государству иллюстрируется его оценкой Римского государства, поэтому следует помнить, что, когда Августин говорит о государстве, он всегда имеет в виду Римскую империю,

${ }^{7}$ Cm.: Ibid. P. 43-44.

${ }^{8}$ Ibid. P. 52.

${ }^{9}$ См.: Августин Блаженный. Творения : в 4 т. Т. 3 : О Граде Божьем. СПб., 1998. C. $190,233$.

${ }^{10}$ Там же. С. 81. 


\section{Вестник ВГУ. Серия: Право}

хотя наполненная насилием и несправедливостью, она неизменно пробуждала в богослове патриотические чувства, и именно ее имел в виду святой Августин, когда писал свой трактат «De civitate Dei» («O Граде Божьем», 413-427 гг. $)^{11}$.

Справедливо утверждение Г. Г. Майорова о том, что отношение Августина к Римской империи достаточно сложно. С одной стороны, ее история изображается в «De civitate Dei» почти исключительно как история сплошных преступлений; с другой стороны, то немногое, что он говорит о ней положительного, имеет немалый вес. В спорах с донатистами он становится даже на ее защиту, а в ранних сочинениях он просто преисполнен римского патриотизма ${ }^{12}$.

По мнению автора, Августин, называя единственной истинной добродетелью благо человека, не отказывал в ней Римскому государству. Римляне, подобно другим народам, за исключением еврейского, чтили ложных богов, поэтому в качестве цели своей жизни, высшей справедливости и добродетели они использовали собственное мерило - свободу. «Подчиненное положение, - указывает богослов, - казалось им бесславным, положение же господствующее и повелевающее - славным, поэтому и саму отчизну они желали прежде всего видеть свободной, а затем господствующей» ${ }^{13}$. В связи с этим с особой любовью и уважением Августин описывает время изгнания царя Тарквиния и период консульства. Правители были названы консулами, а не царями или господами, так как неизменно обладающая характером недоступности царская власть была сочтена чрезмерной гордостью господствующих, а не истинным порядком управления. Об этом периоде Августин пишет: «Город, став свободным, усилился за короткое время до необыкновенной степени. Итак, римляне совершили много великого сперва из любви к свободе, а потом - из любви к господству и из страстного желания доброго о себе мнения и славы» ${ }^{14}$.

Отметим также, что Августин, будучи ревностным христианином и, тем более, занимая епископский пост, не мог не подвергать жесткой критике бывше-языческий Рим. В «Граде Божьем» четко прослеживается восхищение и похвала тем публичным деятелям, которые игнорировали языческий культ либо ограничивали его. Так, обращаясь к древним римлянам, он говорит о Сципионе: «Этой душевной язвы и заразы боялся

44 Сципион, когда запрещал строить театры... Он не думал, что государство может быть счастливым, если его стены будут стоять, а нравы падут. Но для вас гораздо большее значение имеет то, чем прельстили вас бесчестные демоны» ${ }^{15}$.

Еще одно основание значительного числа негативных высказываний о Римском государстве заключается в следующем: на рубеже III и

${ }^{11}$ См.: Августин Блаженный. Указ. соч.

12 См.: Майоров Г. Г. Формирование средневековой философиии. М., 1979. C. 335 .

${ }^{13}$ Августин Блаженный. Указ. соч. С. 213.

${ }^{14}$ Там же.

15 Там же. С. 50. 


\section{Государственная власть. Законодательный процесс...}

IV вв. (время наибольшей научной продуктивности Августина) империя находилась в глубоком кризисе и упадке, вызванными различными причинами, на которых мы не будем заострять внимание. Однако одной из таких причин называется легализация христианства и последующее возведение его в ранг государственной религии. Подобные высказывания не соответствовали действительности, и Августин Блаженный поспешил это доказать. Исследование истории Рима, его критика Римского государства обусловлены необходимостью оправдать христианство, показать, что именно оно является единственной возможной истиной, и что «разложение» Рима имеет более глубокие причины и основания.

Итак, в Римской империи в качестве важнейшей задачи и высшего служения политической власти рассматривалось сохранение существующего в государстве порядка от различного рода внутренних и внешних угроз. Жители Рима весьма ценили предоставленные им гарантии права и мира, а само государство воспринималось как воплощение и гарант спокойствия, безопасности и верховенства права. В связи с этим возникают сразу два вопроса: 1) соответствует ли это христианскому видению государства и 2) отвечает ли тенденциям современного мира.

В одном из публичных выступлений Й. Ратцингер поднимает эту тему, обозначая проблему очень коротко - «изменять или сохранять?» ${ }^{16}$. Иными словами, должна ли современная власть стремиться к стабильности или путь власти есть лишь путь реформ?

Обосновывая актуальность вопроса, Й. Ратцингер замечает, что в наше время требования широкомасштабных реформ и обещания таковых стали абсолютной нормой. Ученый поясняет свою точку зрения следующим образом: несмотря на то что современное общество достигло небывалого доселе благосостояния и свободы, мир, тем не менее, ощущается как труднопереносимый, а государства не в состоянии удовлетворить потребности своих граждан. Отсюда вытекают требования широкомасштабных реформ, и главной задачей каждого государства становится не сохранение сложившегося порядка, а необходимость его преодоления. При этом партии, претендующие на власть, обещают многочисленные перемены. «Становится понятно, - комментирует Й. Ратцингер, - почему слово «консервативный» стало восприниматься как одиозное и почему мало кто хочет казаться консерватором» ${ }^{17}$. Данная проблема ранее ставилась немецким теологом итальянского происхождения Романо Гвардини вдохновителем и учителем Й. Ратцингера, к трудам которого папа на покое не единожды обращается.

В работе «Конец нового времени» ${ }^{18}$ Гвардини достаточно четко объясняет причины, побуждающие политиков к бесконечному реформированию. Вначале теолог справедливо замечает, что политика всегда была

${ }^{16}$ Cм.: Ratzinger J. Europe Today and Tomorrow: Addressing the Fundamental Issue. P. 43.

${ }^{17}$ Ibid.

${ }^{18}$ См.: Гвардини Р. Конец нового времени // Феномен человека. Антология. M., 1993. 


\section{Вестник ВГУ. Серия: Право}

борьбой исторических носителей власти, которые стремились обрести власть и организовать ее по своему усмотрению. Однако в период Средневековья политика являлась частью общего нравственно-религиозного порядка. Это значит, что государство и церковь как две формы Божьего владычества на земле представляли собой целостность - для них применялись единые основания и оценки деятельности, поэтому «где совершалась несправедливость, там она совершалась с нечистой совестью ${ }^{19}$.

Со временем ситуация кардинально меняется. Разделение политики и морали первым провозглашает Макиавелли, за ним следуют другие. Так, Томас Гоббс возводит государство в абсолют, ему оно представляется полным господином и судьей человеческой жизни. Огюст Конт, а за ним и другие позитивисты даже выступают против невмешательства государства в частную жизнь граждан.

Деятельность политиков Нового времени, по мысли Р. Гвардини, превращается в нечто, самостоятельно создающее для себя нормы, мерила и оценки поведения, которые на практике сводятся лишь к задачам достижения и удержания власти. «При этом любая несправедливость, мотивируемая этими задачами, - говорит ученый, - совершается не только с чистой совестью, но даже со своеобразным сознанием исполняемого долга ${ }^{20}$.

Как полагает Р. Гвардини, главный источник этой опасности кроется в самом феномене власти и его восприятии. Современный человек убежден, что любое усиление власти представляет собой прогресс, ведь с ней возрастает надежность, уверенность, насыщение материальными и духовными ценностями - благосостояние и чувство удовлетворенности. На самом же деле, власть есть многозначное понятие, она может как строить, так и разрушать, и то, чем она станет в действительности, зависит от многих фракторов, в том числе от целей, ради которых она используется,

은 и даже от настроений ее носителей. Ученый пишет: «Власть над сущим -

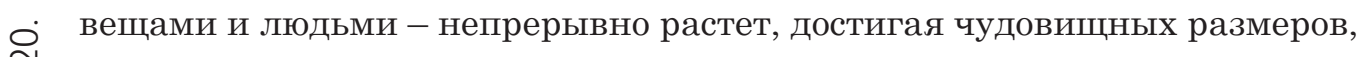
尺े в то время как ни серьезность ответственности, ни ясность совести, ни сила характера не поспевают за этим ростом. Оказывается, что современный человек не дорос до правильного распоряжения властью, более

46 того, он даже не осознает проблемы, в лучшем случае - видит некоторые внешние опасности» ${ }^{21}$.

Следствием подобного восприятия становится злоупотребление властью, и в качестве ярчайшего примера такого злоупотребления Р. Гвардини приводит действия политиков во время Второй мировой войны. Что примечательно, он не упоминает конкретных имен, не анализирует поведение отдельно взятых государственных деятелей, но лишь в общем характеризует военный и послевоенный период как апогей забвения духовных ценностей, когда единственным средством решения всех проблем

\footnotetext{
${ }^{19}$ Гвардини Р. Конец нового времени. С. 254.

${ }^{20}$ Там же. С. 255.

${ }^{21}$ Там же. С. 280.
} 
стала жестокая сила. Именно тогда неправильное использование власти превратилось в норму.

Жесткость консерватизма Р. Гвардини может поначалу показаться чрезмерной, однако не все столь однозначно. В данном случае сдерживание власти не есть бездумное отрицание любого прогресса, но необходимость установления над ним нравственного контроля. Замечательную мысль по этому поводу проводит Й. Ратцингер: «...Вера не заменит разума, но может помочь ясному осознанию важнейших ценностей» ${ }^{22}$.

Непосредственно обращаясь к трудам Й. Ратцингера, мы встречаем концептуальную теорию природы и структуры власти. Основные моменты теории изложены в книгах «Новая песнь для Господа: вера в Христа и литургия сегодня» ${ }^{23}$ и «Церковь, экуменизм и политика» ${ }^{24}$. Кроме того, отдельные вопросы освещены во время выступления на конференции, организованной Католической Баварской академией 19 января 2004 г. Доклад Й. Ратцингера «Was die Welt zusammenhält. Vorpolitische moralische Grundlagen eines freiheitlichen Staates» ${ }^{25}$ был переведен на русский язык и опубликован в книге «Диалектика секуляризации. О разуме и религии» ${ }^{26}$.

Говоря о природе власти, Й. Ратцингер вначале обращается к феномену бессознательного страха, который испытывают люди перед авторитетным верховенством. Происхождение и сущность этого страха ученый сводит к трем основным компонентам. Первый - это природно-психологическое стремление к власти, невозможность удовлетворения которого влечет за собой фрустрацию. Й. Ратцингер настаивает на том, что подобная потребность существует у всех людей: «Мечта о власти, мечта о том, чтобы управлять всем по своей воле и таким образом свободно и без страха утвердить себя в мире, присутствует в каждом человеке. Но для большинства людей это остается мечтой» ${ }^{27}$.

Невозможность осуществлять управление самостоятельно влечет за собой страх от того, что власть оказывается в руках неких людей, которые воспринимаются нами как единый мощный управленческий аппарат. В этом заключается второй компонент - страх перед анонимностью. Вследствие того, что государственная власть носит институциональный характер, в сознании человека отделена от личности того или иного руководителя, главы государства или члена правительства, находящихся в данный момент у власти. Эти последние в глазах управляемых предста!T ют скорее как агенты государства, при этом сама власть остается обезли-

\footnotetext{
${ }^{22}$ Ратиингер Й. Ценности в эпоху перемен. М., 2007. С. 30.

${ }^{23}$ См.: Ratzinger J. A new song for the Lord: faith in Christ and liturgy today. New York, 1996. Crossroad Publishing Co.

${ }^{24}$ CM.: Ratzinger J. Church, Ecumenism and Politics. New Endeavors in Ecclesiology. San Francisco, 2008.

25 Чем держится мир. Дополитические моральные основы либерального государства.

${ }^{26}$ См.: Хабермас Ю., Ратцингер Й. Диалектика секуляризации. О разуме и религии. М., 2006.

${ }^{27}$ Ratzinger J. A new song for the Lord: faith in Christ and liturgy today. P. 27.
} 


\section{Вестник ВГУ. Серия: Право}

ченной, неуловимой и, следовательно, неподконтрольной. Й. Ратцингер заключает: «Мы обнаруживаем, что власть - в руках других людей, или, что еще хуже, она предстоит нам как анонимная сила, истинные носители которой остаются неуловимыми. Тогда мы начинаем ощущать власть не как надежду, а как кошмар и угрозу» ${ }^{28}$.

Третий и последний компонент страха перед властью заключается, по мысли Й. Ратцингера, в наличии арсенала средств, которым обладают властные структуры. В настоящее время абсолютно каждое государство имеет силовые, технические и экономические механизмы для защиты своих граждан, которые постоянно совершенствуются, согласно динамике развития мирового сообщества. Вопрос о контроле над этим развитием, по мнению Й. Ратцингера, является насущным как никогда: «Человек сам создал технику, чтобы властвовать над природой, и вот она оборачивается против него и ему угрожает, становясь властью, ускользающей из его рук, господствующей над ним больше, нежели он господствует благодаря ей» ${ }^{29}$.

Несмотря на то что страх действительно является одной из основных составляющих природы власти, было бы несправедливо ограничиться только им. Поэтому Й. Ратцингер выделяет еще один элемент сущности власти - надежду. Такой неожиданный вывод он делает, проводя параллель с властью Божественной. Она, будучи идеалом, обладает всеми тремя компонентами страха, которые были раскрыты нами выше. Тем не менее на протяжении многих веков люди безоговорочно признавали эту власть и подчинялись ей. Но может ли какая-то власть так долго сохранять свой авторитет, зиждясь только на страхе? Очевидно, что этого недостаточно.

Божественная власть является идеальным воплощением этого фе-номена, и, раскрывая формулу такой «идеальной» власти, Й. Ратцингер обращается к текстам Священного Писания. Ученый исходит из двух библейских текстов, показывающих, чем не является и чем является могущество Бога. Они же проясняют истинную его природу.

Первый отрывок - третье искушение Иисуса Христа (Mdp 4, 8-10): дьявол возносит Иисуса на очень высокую гору и показывает Ему все царства мира. Здесь дьявол говорит о себе как о настоящем властителе мира, обладающем всей властью и дающем ее, кому он хочет. Он предлагает Иисусу власть «со всеми ее соблазнами».

Классические святоотеческие толкования отрывка называют его не иначе, как «искушение властью. Иоанн Златоуст комментирует его следующим образом: дьявол предлагает Иисусу своеобразную альтернативу отречься от Бога и Его власти, отказавшись от той величайшей миссии, с которой Он пришел на землю - искупление человеческого рода путем страданий и крестной смерти. Вместо этой дьявол предлагает Ему иную власть - свою - которая не требует ни страданий, ни смерти. Вместо них он предлагает устроить то царство, о котором мечтали иудеи, а вместе с

\footnotetext{
${ }^{28}$ Ratzinger J. A new song for the Lord: faith in Christ and liturgy today. P. 29.

${ }^{29}$ Ibid. P. 27.
} 
Государственная власть. Законодательный процесс...

ним к Христу придут почести и богатства, роскошь и «всяческие угождения плоти» ${ }^{30}$. Таким образом, необходимо сделать выбор: с одной стороны, это власть, которую обещал Бог - «всякая власть на небе и на земле» (Мф. $28: 18)$, но цена ее - крестные муки и смерть; с другой - власть дьявола, столь близкая и понятная человеческой природе, и цена ее куда ниже всего лишь признание дьявольского могущества: «Все это дам Тебе, если, пав, поклонишься мне» (Мф. 4:9).

Подобные выводы делает и Й. Ратцингер, отмечая, что в данном случае «соблазн власти» - есть «чувство возможности делать, что я хочу, доставлять себе все удовольствия, какие я хочу, располагать всем, повсюду занимать первые места. Никакое удовольствие не возбраняется, любая авантюра возможна, все падают перед тобой на колени. Ты имеешь право на все, что хочешь, и можешь достичь всего, что хочешь. Этой своеобразной карикатурой Божьего могущества дьявол неустанно затуманивает разум человека и пародирует свободу Божию» ${ }^{31}$. Однако Иисус отвечает: «Отойди от Меня, сатана, ибо написано: Господу Богу твоему поклоняйся, и Ему одному служи» (Лк. 4:8). Он выдерживает искушение, поскольку высшим законом, не допускающим никаких отступлений, для Него была воля Его Отца.

Второй отрывок Нового Завета, который также связан с темой власти, это последняя сцена Евангелия от Матфея: Христос призывает апостолов на гору, чтобы дать обетование и напутствие. Он снова на горе, однако созерцает не одни только земные царства, но также иные миры: «Дана мне всякая власть на небе и на земле» (Мф. 28:18).

Й. Ратцингер отмечает, что власть, которую Иисус Христос отказался принять от дьявола, теперь реально Ему принадлежит. Но природа этой новой власти совсем другая: она происходит из другого источника и охватывает все миры - «и небо, и землю, и вечность вплоть до ее последних пределов и за ними» ${ }^{32}$.

Как видно, ученый противопоставляет власть, которую предлагает дьявол, той власти, которой наделяет Бог. Власть-искушение имеет гедонический характер: ее цель - земные удовольствия, а методы - самовластие, деспотизм и отсутствие ответственности. Власть же, которую Иисус провозглашает во втором отрывке, является радикальной антитезой произвола обладания.

Й. Ратцингер описывает ту «идеальную» природу и формулу власти, которая провозглашается Иисусом Христом, в полной мере Им реализуется, и носителями которой становятся Его ученики. Ратцингер последовательно формирует такую концепцию, начиная с лингвистического анализа понятий, которые употребляются в Писании.

Греческий текст Нового Завета для обозначения власти употребляет

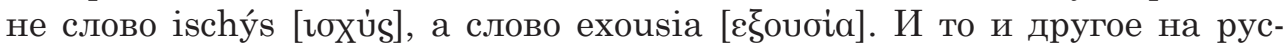

\footnotetext{
${ }^{30}$ Иоанн Златоуст. Толкование Евангелия от Матфея : в 2 т. М., 2017. Т. 1. C. 253 .

${ }^{31}$ Ratzinger J. A new song for the Lord: faith in Christ and liturgy today. P. 34.

${ }^{32}$ Ibid.
} 


\section{Вестник ВГУ. Серия: Право}

ский язык переводится как «власть», однако греческий язык различает эти понятия. Первое - ischýs - означает силу, присущую человеку, некое объективное могущество; второе - exousia - по-гречески обозначает право что-либо делать, право на что-то, укорененное в самой юридической структуре государства.

В целях лучшего понимания проведем параллель с более распространенным в современном мире английским языком. В общем смысле понятие «власть» обозначается словом power, которое аналогично греческому ischýs и употребляется в значении «мощь, могущество действовать определенным образом». Наиболее близким аналогом греческого понятия exousia в английском языке выступает термин authority, который переводится на русский как "власть, совокупность полномочий», но фрактически означает только легитимную власть - властную структуру, которая законным способом наделена полномочиями. Это слово означает возможность действовать на основании права: мандат, разрешение, полномочие.

Й. Ратцингер отмечает, что само слово, употребляемое в Библии для обозначения власти Иисуса Христа, уже является указанием, помогающим глубже понять природу этой власти: «идеальная» власть должна «исходить из послушания, то есть из отношения, которое суть ответственность бытия, ответственность истины и блага» ${ }^{33}$. Фактически это означает, что власть укореняется, прежде всего, во внутреннем нравственном порядке и потому берет на себя ответственность.

Подобные идеи уже были высказаны Р. Гвардини. В работе «Спаситель в мифре, откровении и политике» он писал: «Все существование Иисуса есть преобразование власти в смирение и послушание воле Отца. Послушание не есть нечто вторичное, поскольку оно составляет самую суть Его существа. Его власти неведомы внешние ограничения, но лишь одно внутреннее: воля Отца, принятая совершенно свободно» ${ }^{34}$.

Раскрывая мысль обоих богословов, отметим, что «воля Отца», которая

을 являлась ограничением власти Иисуса Христа, есть конкретное требование для любой власти. Государственная власть должна, прежде всего, подчиняться целям, ради которых она была создана - достижение гармонии общественной организации. Так же, как воля Бога, квинтәссенция мирового порядка и истины, становится главным источником власти

50 Иисуса, так общее благо и взаимное согласие должны выступать единственным обоснованием власти в государстве.

Обобщая вышесказанное, выделим два типа власти - господствующая власть и нравственная власть. Первая может придерживаться внешних формальных правил, но природа ее определяется конструкциями «я могу», «я располагаю». Господство предстает антитезой смирению, а обретаемая свобода - антитезой ответственности. Истина становится прерогативой власть имущих, а всякий этический компонент отрицается

\footnotetext{
${ }^{33}$ Ratzinger J. Church, Ecumenism and Politics. New Endeavors in Ecclesiology. P. 265 .

${ }^{34}$ Гвардини Р. Спаситель в мифе, откровении и политике // Философские науки. 1992. № 2. С. 98.
} 


\section{Государственная власть. Законодательный процесс...}

или игнорируется. В природе этой власти - делать вещи и людей объектами или функциями на службе собственной воли.

Второй тип - exousia. В ее природе три главных элемента: во-первых, такая власть воспринимается не сама по себе, она - часть общества и, значит, общественный интерес лежит в основе ее действий. Отсюда следует второй компонент - ответственность перед теми, кто эту власть предоставил. Структура exousia позволяет преодолеть страх перед обезличенностью и неподконтрольностью власти и делает возможным привлечение к ответственности отдельных ее носителей. Третий и последний элемент exousia - это идеологическая основа. Ни власть, ни даже государство сами по себе не могут выступать источником истины и морали, поэтому только существование общепризнанных ценностей и твердых духовных основ, которыми никто не может манипулировать, дает гарантию свободы и уважения человеческого достоинства.

В случае деформации структуры exousia или ее отсутствии необходимость полного послушания власти в духе библейского принципа «нет власти не от Бога» отменяется. В Катехизисе католической церкви говорится: «Совесть обязывает гражданина не следовать предписаниям гражданских властей, если они противоречат нравственным законам, основополагающим правам человека и учению Евангелия» ${ }^{35}$.

В данном случае отказ от повиновения оправдывается различием между служением Богу и служением политическим властям: «Должно повиноваться Богу больше, чем человекам» (Деян. 5:29); «отдавайте кесарево кесарю, а Божие Богу» (Мф. 22:21). Слова же «нет власти не от Бога» (Рим. 13,1$)$ означают, что установлением Бога является сам институт власти и, соответственно, возможность осуществления Божественных замыслов через властные структуры - «ты не имел бы надо Мною никакой власти, если бы не было дано тебе свыше» (Ин. 19:11). Таким образом, понятие exousia (власть, авторитет) в новозаветном контексте означает положительную в этическом смысле власть.

Центральная проблема сегодня, на наш взгляд, прекрасно сформулирована Р. Гвардини: «У человека есть власть над вещами, но пока еще нет власти над своей властью» ${ }^{36}$. Й. Ратцингер приводит в связи с этим интересную метафору: «Наконец достигнутая власть для человека становится подобна добыче для вора - он ревностно ее защищает и жадно ею пользуется. На самом деле, такое поведение является признаком бессилия: он берет то, что ему не принадлежит» ${ }^{37}$.

Продолжим эту мысль: подобно вору, ожидающему, что вскоре его добычу отберут, человек стремится как можно әффективнее воспользоваться своей властью - приумножить ее, взрастить и, благодаря этому, обезопасить себя.

${ }^{35}$ Катехизис католической церкви. Ст. 2242. М., 2001. С. 522.

${ }^{36}$ Гвардини Р. Спаситель в мифе, откровении и политике. Теолого-политические раздумья // Философские науки. 1992. № 2. С. 159.

${ }^{37}$ Ratzinger J. A new song for the Lord: faith in Christ and liturgy today. P. 30. 


\section{Вестник ВГУ. Серия: Право}

Таким образом, на основе проведенного исследования выделим ряд следующих моментов.

1. В социальной доктрине католической церкви феномен власти активно исследовался католическими мыслителями и в настоящее время представляет собой одну из центральных проблем христианского социального учения.

2. Раскрывая вопросы сущности государственной власти, Й. Ратцингер опирается на традиционное учение Отцов Церкви - в первую очередь, А. Аврелия, согласно которому государство является необходимым социальным институтом, обеспечивающим стабильность и спокойствие; его создание обусловлено человеческой природой, и следовательно, каждый человек должен признавать нравственное значение и упорядочивающую фрункцию государственной власти.

3. В то же время признания и уважения достойна не всякая власть, но лишь та, действия которой направлены на установление общественного порядка и служение общему благу. Согласно воззрениям Й. Ратцингера, оценке подлежат не личные достижения и характеристики правителей, не их мировоззрение и благие намерения, но лишь фактические действия исполнение обязанностей, принятие ответственности, т. е. объективная способность к реализации функций публичной власти.

4. В качестве одной из сущностных характеристик феномена власти Й. Ратцингер выделяет метафизический бессознательный страх, который и располагает к повиновению. Страх перед властью включает в себя три компонента - страх перед собственным бессилием, страх перед анонимностью власти и страх перед арсеналом средств принуждения. Наличие бессознательного страха присуще любому виду власти - как земной власти людей, так и власти Бога.

5. На основе экзегетического анализа греческих текстов Нового Завета Й. Ратцингер излагает сущностную концепцию феномена власти, основанную на условном выделении двух видов власти. Первый вид - господствующая власть: ее цели и методы обусловлены, как правило, личными устремлениями правителей, и поэтому такая власть легко может перерасти в деспотизм и тиранию. Второй вид - нравственная власть exousia - власть, которая выбирает общее благо и общественный интерес в качестве главной своей цели, готова нести ответственность за все свои действия. Нравственная власть действует на основании этических принципов и общепризнанных ценностей. Именно такая власть становится антитезой произвола и отвечает замыслу творения.

Всероссийский государственный университет юстиции (РПА Минюста Росcuu)

Костенникова Е. А., соискатель кафбедрь теории, истории государства и права и фблософбии

E-mail: kate-vrn@mail.ru
All-Russian State University of Justice (RLA of the Ministry of Justice of Russia)

Kostennikova E. A., Post-graduate Student of the Theory, History of State and Law and Philosophy Department

E-mail:kate-vrn@mail.ru 